Ilmu Pertanian (Agricultural Science)

Vol. 2 No. 2 August, 2017 : 056-063

Available online at http://journal.ugm.ac.id/jip

DOI: doi.org/10.22146/ipas.17991

\title{
The Optimum Dose of Nitrogen, Phosporus, and Potassium to Improve Soybean (Glycine max (L) Merr) Productivity on Kayu Putih (Melaleuca cajuputi) Stands
}

\author{
Roni Ismoyo Jati ${ }^{1 *}$, Tohari ${ }^{1}$, Priyono Suryanto ${ }^{2}$ \\ ${ }^{1}$ Department of Agronomy, Faculty of Agriculture, Universitas Gadjah Mada \\ Jln. Flora no. 1, Bulaksumur, Sleman, Yogyakarta 5528, Indonesia \\ ${ }^{2}$ Department of Silviculture, Faculty of Forestry, Universitas Gadjah Mada \\ Jln. Agro no. 1, Bulaksumur, Sleman, Yogyakarta 55281, Indonesia \\ *Corresponding email: ismoyojatironi@gmail.com
}

Received: $16^{\text {th }}$ January 2017 ; Revised: $5^{\text {th }}$ August 2017 ; Accepted: $28^{\text {th }}$ August 2017

\begin{abstract}
It was necessary to obtain optimum dose of nitrogen, phosphorus, and potassium obtained through fertilisation in order to improve productivity in the intercropping. Kayu putih tree was cultivated in Yogyakarta for oil production, and the inter-row was designed for intercropping plants, including soybean. The objective of present study was to obtain optimum dose of urea, SP-36, and $\mathrm{KCl}$ for soybean intercropped with kayu putih. The experiment was conducted in Menggoran Forest Resort (RPH Menggoran), Playen Forest Section (BDH Playen), Yogyakarta Forest Management District (KPH Yogyakarta) using split-split plot design. The main plot was urea, subplot was SP-36, and sub-subplot was $\mathrm{KCl}$. Fertilisation consisted of three levels $\left(0,25,50 \mathrm{~kg} \mathrm{ha}^{-1}\right.$ of urea), $\left(0,150,300 \mathrm{~kg} \mathrm{ha}^{-1}\right.$ of SP-36) and $(0,75$, $150 \mathrm{~kg} \mathrm{ha}^{-1}$ of $\left.\mathrm{KCl}\right)$. The results showed that application of $50 \mathrm{~kg} \mathrm{ha}^{-1}$ urea, $300 \mathrm{~kg}^{\mathrm{ha}} \mathrm{ha}^{-1} \mathrm{SP}-36$, and $150 \mathrm{~kg}$. ha- $\mathrm{KCl}$ increased N, P, K uptake per hectare as much as $16.23 \mathrm{~kg} \mathrm{~N} \mathrm{ha}^{-1}, 86.27 \mathrm{~kg} \mathrm{P} \mathrm{ha}^{-1}, 40.02 \mathrm{~kg} \mathrm{~K} \mathrm{ha}^{-1}$, respectively. There was positive interaction between urea and SP-36, SP-36 and $\mathrm{KCl}$ at leaf area, photosynthetic rate, number of seeds per plants, seed weight per plants, and seed weight per hectare. Under kayu putih intercropping, optimum dosage of urea, SP-36 and $\mathrm{KCl}$ were $0,298.03$ and $87.12 \mathrm{~kg} \mathrm{ha}^{-1}$, respectively. These combination enabled to produce maximum seed weight of 2.01 tons. ha-1 .
\end{abstract}

Keywords: Kayu Putih, Optimum Dose of Nitrogen, Phosphorus and Potassium, Soybean Fertilisers, Soybean Productivity

\section{INTRODUCTION}

Soybean (Glycine max (L) Merr) is a popular seasonal crop and is cultivated by Indonesian farmers because of its role in public life. A lot of processed foods are derived from soybeans raw materials, such as tempe, kecap, tauco, and others. More diverse processed foods derived from soybean raw material are expected to increase soybean demand among the public in the next years.

Average soybean projected demand issued by National Development Planning Agency in year 2012-2019 is approximately 2,846,250 tons. This figure is still very high due to the projected domestic soybean production only reached 924.250 tons in 2012-2019. There is $1,922,000$ tons deficit (BPPN, 2013). Lower production of soybeans in the country is caused by: 1) the lack of area for soybean cultivation, and 2) low productivity of soybeans grown by farmers.
Reduction in agricultural land is due to land convertion and the potential for agriculture to non-agricultural activities, land convertion from soybean cultivation replaced with other crops. Average nationwide productivity of soybean from in 1993-2015 ranged from 1.1 to 1.5 tons $\mathrm{ha}^{-1}$. To overcome this problem, land intensification and balanced fertilisation can be used (BPS, 2015). Popularity of soybean in agroforestry is increasing, as proven by the implementation of agroforestry system done by farmers in Gunungkidul regency by planting soybeans between kayu putih stands.

Intercropping is a soil management technique by combining tree and seasonal crop components in the same space and time. Intercropping is one of forestry programs aimed to maintain food security of the community around the forest. Intercropping on kayu putih forests in the context of food security is an important part of the forest movement for food (Suryanto et al., 2017). Several researches have been conducted, 
such by Ceunfin et al. (2015) and Purba et al. (2015) who examined the planting distance and zone between black soybean (Glycine soja L.) Merrit) and maize (Zea mays) in intercropping of kayu putih and the effect of mycorrhizal application on the growth and yield of soybean (Sinaga et al., 2016). There was no negative effects of kayu putih on seasonal crops in the field, such as shade effects and alelopati (Ceunfin et al., 2015). Fertilisation is done by farmers to improve crop productivity. However, the fertilisation activities done by farmers sometimes do not refers to the recommended dosage by local department of agriculture, so its use is relatively according to forecasts and unbalanced. The use of fertiliser with a too high or too low dosage will lead to a decrease in plant responses.

Nitrogen, phosphorus, and potassium are macro nutrient which are contained in fertilisers and are absolutely needed by plants. Gardner et al. (1991) described some of the symptoms shown by plants for excessive nitrogen which can cause greener leaves, denser leaves, a decrease in flower production, and prone to pests and disease. Meanwhile nitrogen deficiency would interfere with growth process, the plants become stunted, the leaves turn yellow, yield and plant dry weight are reduced. Excessive phosphorus will interfere with the absorption of micronutrients, such as iron $(\mathrm{Fe})$, copper $(\mathrm{Cu})$, and zinc $(\mathrm{Zn})$. Phosphorus deficiency can cause purplish colored older leaves tend to be gray, brown colored edges of the leaves turn, the growth of small leaves, and slow growth phase, as well as stunted plants. Potassium is an important nutrient for plants. Application potassium to the plant will cause the absorption of calcium $\left(\mathrm{Ca}^{2+}\right)$ and magnesium $\left(\mathrm{Mg}^{2+}\right)$ to be disturbed. Its deficiency might show responses, such as like flowers fall off easily, the leaves at the bottom to be dry or there are spots, scorched leaves, and leaf edges curl downward.

Through a balanced fertilisation, soybean productivity is expected to be improved and could provide information to farmers. Thus this study aims to obtain the optimum dose of nitrogen, phosphorus, and potassium to improve soybean productivity on kayu putih stands.

\section{MATERIALS AND METHODS}

The research was conducted from February to May 2015 in Menggoran Forest Resort (RPH Menggoran), Playen Forest Section (BDH Playen), Yogyakarta Forest Management District (KPH Yogyakarta). The altitude of the area was $177 \mathrm{~m}$ above sea level and the soybean used was Grobogan varieties. Kayu putih in the study site existing and planted by KPH Yogyakarta with 7-17 years age range and planting distance of 4 × 2 m. Kayu putih cultivation system one of them with pruning the canopy every year for harvest. This field experiment was a response surface estimation to urea, $\mathrm{SP}-36$, and $\mathrm{KCl}$ which was a step to obtain the optimum dose for urea, SP-36, and $\mathrm{KCl}$ for soybean cultivation.

The field experiment was done using split-split plot design, i.e: 1) urea as main plot, 2) SP-36 as subplots, and 3) $\mathrm{KCl}$ as sub-subplots, each consisting of three levels $\left(0,25,50 \mathrm{~kg} \mathrm{ha}^{-1}\right.$ of urea), $\left(0,150,300 \mathrm{~kg} \mathrm{ha}^{-}\right.$ ${ }^{1}$ of SP-36) and $\left(0,75,150 \mathrm{~kg} \mathrm{ha}^{-1}\right.$ of $\left.\mathrm{KCl}\right)$. The dosage refered to a recommendation from Institute for Agricultural Technology Special Region of Yogyakarta (BPTP, 2008). Observations included: 1) soil characteristics, 2) growth components (leaf area, light interception, transpiration rate and photosynthetic rate, N, P, K uptake per hectare), 3) yield component (number of seeds per plants, seed weight per plants and seed weight per hectare). Obtained data from observations were analyzed using Analysis of Variance (ANOVA) according to split-split plot design using SAS software for Windows release 9.1. When differences resulted were significant, individual means were compared using the Duncan's Multiple Range Test (DMRT) at $5 \%$ levels

\section{RESULT AND DISCUSSION}

\section{Soil Characteristics}

Based on soil characteristics observation (Table 1), neutral soil $\mathrm{pH}$ with the organic matter content and C-organic in the poor state. The lack of such material in the soil would affect the availability of N. Buckman and Brady (1969) explained that $\mathrm{N}$ nutrient joined with organic ingredients and changing very complex, protein was converted from the decomposition into nitrate $\left(\mathrm{NO}_{3}{ }^{-}\right)$can then be utilized by microorganisms and plants or lost through the leaching process and

Table 1. Soil chemical properties before sowing

\begin{tabular}{lcc}
\hline \multicolumn{1}{c}{ Parameters } & Mean value & Rating \\
\hline pH H${ }^{2} \mathrm{O}$ & 7.2 & Neutral \\
C-organic (\%) & 1.27 & Low \\
Organic matter (\%) & 2.19 & Low \\
N-kjeldhal (\%) & 0.11 & Low \\
P-olsen $(\%)$ & 28.43 & Moderate \\
Exch. $\mathrm{K}^{+}(\%)$ & 16.71 & Low \\
Exch. $\mathrm{Ca}^{2+}\left(\mathrm{cmol}(+) \mathrm{kg}^{-1}\right)$ & 45.35 & Very high \\
CEC $\left.\left(\mathrm{cmol}^{-1}\right) \mathrm{kg}^{-1}\right)$ & 55.51 & Very high \\
Base saturation $(\%)$ & 85.84 & Very high \\
Texture & & Heavy clay \\
\hline
\end{tabular}

Source: Soil Laboratory of Agriculture Faculty, UGM. 
Table 2. Mean growth component of each treatment

\begin{tabular}{|c|c|c|c|c|}
\hline \multirow[b]{2}{*}{ Treatment } & \multicolumn{4}{|c|}{ Growth Component } \\
\hline & Leaf area $\left(\mathrm{cm}^{-2}\right)$ & $\begin{array}{c}\text { Light interception } \\
(\%)\end{array}$ & $\begin{array}{l}\text { Transpiration rate } \\
\left(\mathrm{mmol} \mathrm{H} \mathrm{H}_{2} \mathrm{O} \cdot \mathrm{m}^{-2} \cdot \mathrm{s}^{-1}\right)\end{array}$ & $\begin{array}{l}\text { Photosynthetic rate } \\
\left(\mu \mathrm{mol} \mathrm{CO} \mathrm{CO}_{2} \cdot \mathrm{m}^{-2} \cdot \mathrm{s}^{-1}\right)\end{array}$ \\
\hline \multicolumn{5}{|l|}{ Urea (kg. ha $\left.{ }^{-1}\right)$} \\
\hline 0 & $1647.60 \mathrm{a}$ & $45.25 \mathrm{a}$ & $0.56 \mathrm{a}$ & $26.75 \mathrm{a}$ \\
\hline 25 & $1975.00 \mathrm{a}$ & $44.14 \mathrm{a}$ & $0.72 \mathrm{a}$ & $31.83 \mathrm{a}$ \\
\hline 50 & $2022.70 \mathrm{a}$ & $43.66 \mathrm{a}$ & $0.70 \mathrm{a}$ & $34.59 \mathrm{a}$ \\
\hline \multicolumn{5}{|l|}{ SP-36 (kg. ha-1) } \\
\hline 0 & $1582.30 \mathrm{~b}$ & $45.20 \mathrm{ab}$ & $0.57 \mathrm{~b}$ & $25.99 \mathrm{c}$ \\
\hline 150 & $1843.10 \mathrm{~b}$ & $38.40 \mathrm{~b}$ & $0.46 \mathrm{~b}$ & $30.80 \mathrm{~b}$ \\
\hline 300 & $2220.00 \mathrm{a}$ & $49.46 \mathrm{a}$ & $0.96 \mathrm{a}$ & $36.38 \mathrm{a}$ \\
\hline \multicolumn{5}{|l|}{$\mathrm{KCl}\left(\mathrm{kg} \cdot \mathrm{ha}^{-1}\right)$} \\
\hline 0 & $1833.10 \mathrm{a}$ & $47.36 \mathrm{a}$ & $0.67 \mathrm{a}$ & $30.60 \mathrm{a}$ \\
\hline 75 & $1738.00 \mathrm{a}$ & $45.87 \mathrm{a}$ & $0.55 \mathrm{a}$ & $28.92 \mathrm{a}$ \\
\hline 150 & $2074.30 \mathrm{a}$ & $39.82 \mathrm{a}$ & $0.77 \mathrm{a}$ & $33.65 \mathrm{a}$ \\
\hline Mean & 1881.81 & 44.35 & 0.66 & 31.05 \\
\hline Urea*SP-36 & $(+)$ & $(-)$ & $(-)$ & $(+)$ \\
\hline Urea*KCl & $(-)$ & $(-)$ & $(-)$ & $(-)$ \\
\hline SP-36*KCl & $(-)$ & $(-)$ & $(-)$ & $(-)$ \\
\hline Urea*SP-36*KCl & $(-)$ & $(-)$ & $(-)$ & $(-)$ \\
\hline
\end{tabular}

Table 3. The interaction of urea and SP-36 fertiliser on leaf area and photosynthetic rate

\begin{tabular}{|c|c|c|c|c|}
\hline \multirow{2}{*}{ Urea $\left(\mathrm{kg} \cdot \mathrm{ha}^{-1}\right)$} & \multicolumn{3}{|c|}{ SP-36 (kg. ha-1) } & \multirow{2}{*}{ Mean } \\
\hline & 0 & 150 & 300 & \\
\hline leaf area & \multicolumn{3}{|c|}{$\mathrm{cm}^{-2}$} & \\
\hline 0 & $1204.90 \mathrm{~d}$ & $1759.30 \mathrm{bcd}$ & $1978.80 \mathrm{abc}$ & 1647.60 \\
\hline 25 & $1526.90 \mathrm{~cd}$ & $2190.60 \mathrm{ab}$ & $2207.70 \mathrm{ab}$ & 1975.00 \\
\hline 50 & $2015.30 \mathrm{abc}$ & $1579.50 \mathrm{bcd}$ & $2473.40 \mathrm{a}$ & 2022.70 \\
\hline Mean & 1582.30 & 1843.10 & 2220.00 & $(+)$ \\
\hline \multicolumn{4}{|c|}{ 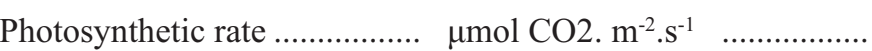 } & \\
\hline 0 & $19.69 \mathrm{~d}$ & $28.64 \mathrm{bcd}$ & $31.92 \mathrm{abc}$ & 26.75 \\
\hline 25 & $23.52 \mathrm{~cd}$ & $35.97 \mathrm{ab}$ & $36.00 \mathrm{ab}$ & 31.83 \\
\hline 50 & $34.76 \mathrm{ab}$ & $27.78 \mathrm{bcd}$ & $41.22 \mathrm{a}$ & 34.59 \\
\hline Mean & 25.99 & 30.80 & 36.38 & $(+)$ \\
\hline
\end{tabular}

Remarks : Number followed by letter the same in the column indicated there was no significant difference according to DMRT at $5 \%$ levels. Sign $(+)$ indicated there was an interaction found between the factors tested.

evaporates into a gas $\left(\mathrm{N}_{2}\right)$. Human activities in agriculture also played a role in the process of losing $\mathrm{N}$ source in the soil (Chen et al., 2014; Qiao et al., 2015; Zhu et al., 2015). $\mathrm{P}$ and $\mathrm{K}^{+}$soil content related to the type of cation and soil texture. Parent material originating from limestone contained $\mathrm{Ca}_{2}^{+}$and base saturation was very high. P nutrient in the soil was very easily adsorbed by $\mathrm{Ca}_{2}{ }^{+}$, forming a phosphate compound $\left(\mathrm{PO}_{4}{ }^{3-}\right)$ or apatite $\left(\mathrm{Ca}_{5}\left(\mathrm{PO}_{4}\right)_{3}\right)$, which was unavailable for plants. There was a relationship between phosphate and lime content. Soil containing phosphates were usually alkaline, so it could not be absorbed by plants (Darmawijaya, 1990). This relationship was also confirmed from the research conducted by Daly et al. (2015) who found a correlation between the content of $\mathrm{Ca}^{2+}$ and $\mathrm{P}$ availability in the soil.

A low content of $\mathrm{K}^{+}$and a high CEC soil was caused by the adsorption of heavy clay minerals type $2: 1$. The main mineral in clay soils was dominated by smectite minerals type $2: 1$, so as to adsorbed $\mathrm{K}^{+}$ 

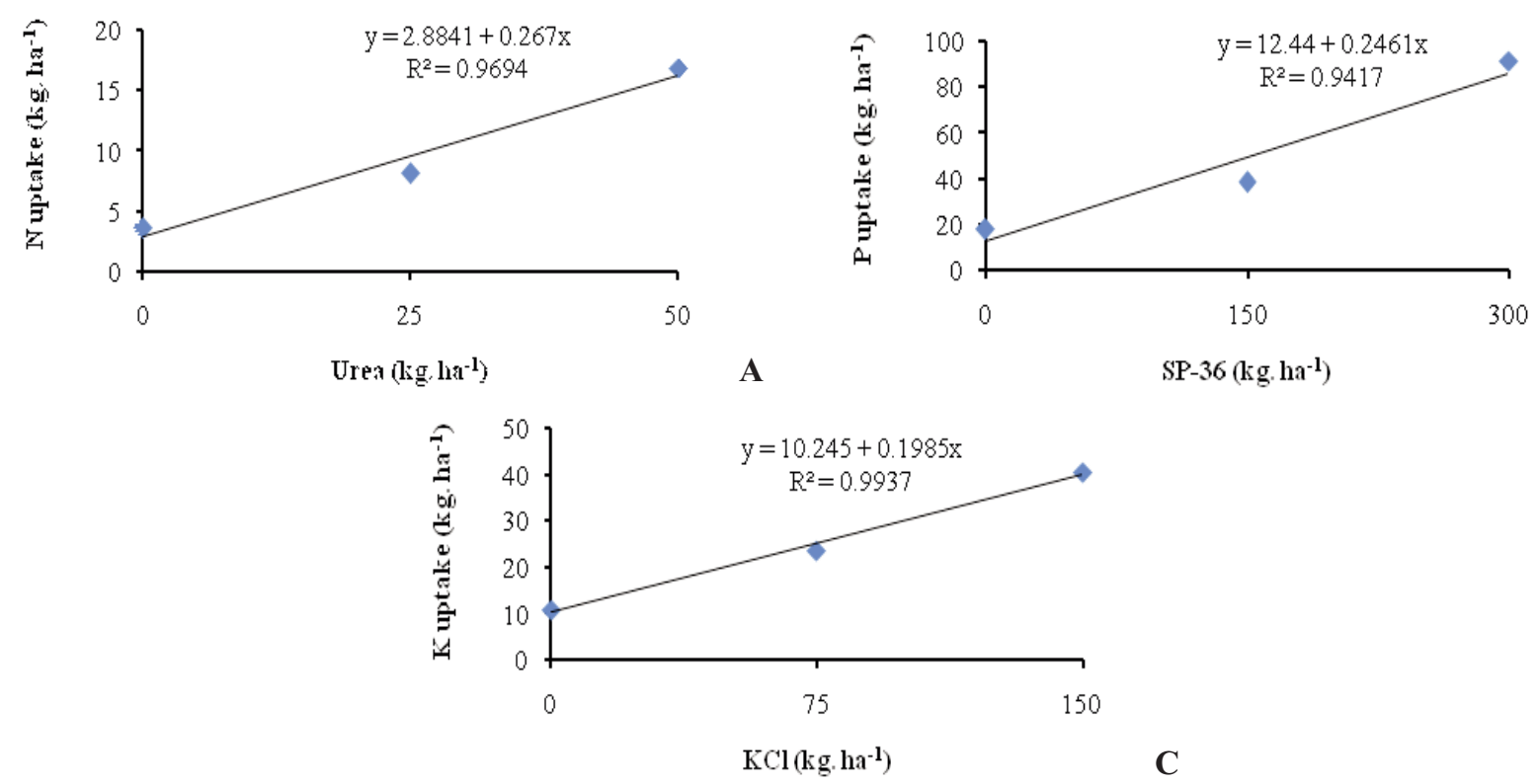

C

Figure 1. The relationship between dose (A) urea, (B) SP-36, (C) $\mathrm{KCl}$ and N, P, K uptake per hectare.

on the clay surface and raise the soil CEC (Prasetyo, 2007).

\section{Growth Component and N, P, K Uptake by Plants}

Observation of the growth components showed that the use of SP-36 fertiliser dosage of $300 \mathrm{~kg} \mathrm{ha}^{-1}$ had a significantly difference compared with SP-36 fertiliser treatment with 0 and $150 \mathrm{~kg} \mathrm{ha}^{-1}$ dosage for leaf area, light interception, transpiration rate, and photosynthetic rate (Table 2). There was a positive interaction among urea and SP-36 and leaf area and photosynthetic rate. Fertilisation performed on soybean with $300 \mathrm{~kg}$. ha ${ }^{-1}$ of SP-36 had a positive effect on growth component. Leaf area would increase when the availability of $\mathrm{P}$ was fulfilled. The role of $\mathrm{P}$ in the growth process was as a constituent of plant tissues, such as nucleic acids, phospholipids, and fitin (Tisdale, 1990). On wheat, P deficiency would cause a disruption in physiological processes and plant growth, especially in leaves (Fernandez et al., 2014).

There was interaction between urea and SP-36 fertiliser treatment (Table 3). The combination resulted in a positive interaction for leaf area and photosynthetic rate. In leaf area and photosynthetic rate, the combination of $50 \mathrm{~kg} \mathrm{ha}^{-1}$ urea and $300 \mathrm{~kg} \mathrm{ha}^{-1}$ SP-36 showed a significant difference compared with the combination of urea and SP-36 $0 \mathrm{~kg} \mathrm{ha}^{-1}$ dosage.

Interactions that occurred between leaf area and photosynthetic rate with urea and SP-36 treatments was predicted to have a correlation with the uptake of $\mathrm{N}$ and $\mathrm{P}$ (Figure 1) through an increase in the rate of transpiration. Research conducted by Chiezey et al. (2009) showed there was an increase in soybean leaf area, transpiration rate, and photosynthetic rate through $\mathrm{P}$ fertilisation. Within plant tissues, nitrogen and phosphorus played a role in the formation of ATP and ADP at the process of energy transfer in photosynthetic. When one of these elements were not available, it would affect energy transfer process in photosynthesis (Gardner et al., 1991).

Based on the results of correlation analysis (Table $4)$, the relationships between transpiration rate $(\mathrm{r}=$ $\left.0.46^{* *}\right), \mathrm{N}$ uptake $\left(\mathrm{r}=0.41^{* *}\right)$, P uptake $(\mathrm{r}=0.50$ $* *), \mathrm{K}$ uptake $\left(\mathrm{r}=0.36^{* *}\right)$ at the photosynthetic rate could be obtained.

Statistical analysis of soybean yield components results showed that 300 and $150 \mathrm{~kg} \mathrm{ha}^{-1} \mathrm{SP}-36$ was significantly different compared with $0 \mathrm{~kg} \mathrm{ha}^{-1}$ SP-36 for number of seeds per plants, seed weight per plants, and seed weight per hectare (Table 5).

Seed was the sink organ for the photosynthetic product. Assimilation formed in the vegetative phase would then be distributed to the establishment of seed pods and filling. In sorghum, seed filling process was influenced by the availability of $\mathrm{N}$ and $\mathrm{P}$ in vegetative phase (Goldsworthy and Fisher,

Table 4. The correlation among variables

\begin{tabular}{lccccc}
\hline & $T R$ & $N U$ & $P U$ & $K U$ & $P R$ \\
\hline$T R$ & 1 & & & & \\
$N U$ & $0.21^{\mathrm{ns}}$ & 1 & & & \\
$P U$ & $0.43^{* *}$ & $0.24^{*}$ & 1 & & \\
$K U$ & $0.24^{*}$ & $0.33^{* *}$ & $0.36^{* *}$ & 1 & \\
$P R$ & $0.46^{* *}$ & $0.41^{* *}$ & $0.50^{* *}$ & $0.36^{* *}$ & 1 \\
\hline
\end{tabular}

Remarks: Number followed by ${ }^{(\mathrm{ns})}$ and $(*)$ indicated no significant and significant difference at $5 \%$ levels, numbers followed by $(* *)$ indicated significant difference at $1 \%$ levels. $T R=$ Transpiration rate; $N U=\mathrm{N}$ uptake; $P U=\mathrm{P}$ uptake; $K U=\mathrm{K}$ uptake; $P R=$ Photosynthetic rate. 
Table 5. Mean yield component of each treatment

\begin{tabular}{|c|c|c|c|}
\hline \multirow[b]{2}{*}{ Treatment } & \multicolumn{3}{|c|}{ Yield Component } \\
\hline & $\begin{array}{c}\text { Number of } \\
\text { seeds/plants }\end{array}$ & $\begin{array}{c}\text { Seed weight/plants } \\
(\mathrm{g})\end{array}$ & $\begin{array}{c}\text { Seed weight/hectare } \\
\text { (tons) }\end{array}$ \\
\hline \multicolumn{4}{|l|}{ Urea (kg. ha-1) } \\
\hline 0 & $36.59 \mathrm{a}$ & $5.92 \mathrm{a}$ & $1.54 \mathrm{a}$ \\
\hline 25 & $42.12 \mathrm{a}$ & $6.89 \mathrm{a}$ & $1.79 \mathrm{a}$ \\
\hline 50 & $40.66 \mathrm{a}$ & $6.78 \mathrm{a}$ & $1.75 \mathrm{a}$ \\
\hline \multicolumn{4}{|l|}{ SP-36 (kg. ha-1) } \\
\hline 0 & $35.43 \mathrm{~b}$ & $5.71 \mathrm{~b}$ & $1.47 \mathrm{~b}$ \\
\hline 150 & $41.38 \mathrm{a}$ & $6.64 \mathrm{a}$ & $1.73 \mathrm{a}$ \\
\hline 300 & $42.56 \mathrm{a}$ & $7.24 \mathrm{a}$ & $1.88 \mathrm{a}$ \\
\hline \multicolumn{4}{|c|}{$\mathrm{KCl}\left(\mathrm{kg} \cdot \mathrm{ha}^{-1}\right)$} \\
\hline 0 & $38.50 \mathrm{a}$ & $6.26 \mathrm{a}$ & $1.58 \mathrm{a}$ \\
\hline 75 & $39.16 \mathrm{a}$ & $6.61 \mathrm{a}$ & $1.73 \mathrm{a}$ \\
\hline 150 & $41.70 \mathrm{a}$ & $6.72 \mathrm{a}$ & $1.78 \mathrm{a}$ \\
\hline Mean & 39.79 & 6.53 & 1.69 \\
\hline Urea*SP-36 & $(-)$ & $(-)$ & $(-)$ \\
\hline Urea*KCl & $(-)$ & $(-)$ & $(-)$ \\
\hline $\mathrm{SP}-36^{*} \mathrm{KCl}$ & $(+)$ & $(+)$ & $(+)$ \\
\hline Urea*SP-36*KCl & $(-)$ & $(-)$ & $(-)$ \\
\hline
\end{tabular}

Remarks: Number followed by letter the same in the column indicated no significant difference according to DMRT at 5\% levels. Sign (+) and (-) indicated there was an interaction and no interaction found between the factors tested.

1996). Estimated remobilization and translocation process from source to sink which involved $\mathrm{N}$ and $\mathrm{P}$ in the plant tissue was around $62 \%$ and $65 \%$ (Brant and Chen, 2015). So when the availability of these elements at the vegetative phase was fulfilled, they would be used for establishment and seed filling process. The increase in the rate of photosynthetic at a vegetative stage had a positive impact on number of seeds and seed weight.

There was interaction found between the combination of SP-36 and $\mathrm{KCl}$ fertiliser (Table 6). The combination resulted in a positive interaction in number of seeds per plants, seed weight per plants, and seed weight per hectare. In number of seeds per plants, seed weight per plants, and seed weight per hectare, the combination of SP-36 dose $0 \mathrm{~kg} \mathrm{ha}^{-1}$ and $\mathrm{KCl} 0 \mathrm{~kg}$ $\mathrm{ha}^{-1}$ and $150 \mathrm{~kg}$. ha ${ }^{-1}$ did not significantly different. However, both combinations were significantly different compared with SP-36 of $300 \mathrm{~kg} \mathrm{ha}^{-1}$ dosage and $\mathrm{KCl}$ of $75 \mathrm{~kg}$. ha ${ }^{-1}$ dosage. The interaction occured in fertilisation treatment of SP-36 and $\mathrm{KCl}$ was because of the role of these elements in plants. In the majority of plant species, $\mathrm{P}$ and $\mathrm{K}$ was found in large quantities in the seed. Through fertilisation using $\mathrm{P}$ and $\mathrm{K}$, soybean seed yield could be increased (Xiang et al., 2012). P stimulated the establishment of seed, while the functions of $\mathrm{K}$ was in assimilate transportation from leaf to seed (Gardner et al., 1991).

Seed weight per hectare are obtained through the interaction between fertilization SP-36 and $\mathrm{KCl}$ (Table 6) is used as a guide to get a dose of fertilizer optimum soybeans. The equation was $\mathrm{Y}$ (seed weight per hectare $)=1.39^{* *}+0.0055^{\text {ns }} \mathrm{K}(\mathrm{kg} \mathrm{KCl}$ per ha $)$ $+0.0019^{\text {ns }} \mathrm{P}$ (kg SP-36 per ha) $-0.000035^{\text {ns }} \mathrm{K}^{2}+$ $0.0000026^{\text {ns }} \mathrm{PK}-0.0000027^{\text {ns }} \mathrm{P}^{2}$. Coefficient regression for maximum seed weight per hectare using response surface analysis was not significantly different at a dose of SP-36 and $\mathrm{KCl}$. The optimum dosage of urea $0 \mathrm{~kg} \mathrm{ha}^{-1}, \mathrm{SP}-36289.03 \mathrm{~kg} \mathrm{ha}^{-1}, \mathrm{KCl} 87.12 \mathrm{~kg} \mathrm{ha}^{-1}$ gave the maximum seed weight of 2.01 tons. $\mathrm{ha}^{-1}$ (Figure 2). The soybean in the intercropping system of kayu putih about 2 tons. ha ${ }^{-1}$ was a good result compared with the intercropping in fertile sites, such as East Java teak forests. The soybean yields grown in the shade of teak forest with a level of $5-10 \%$ at KPH Padangan, Bojonegoro, Banyuwangi, Jember, and Blitar could produce around 1.2 tons ha $^{-1}$. Meanwhile in Ngawi KPH, soybean productivity was ranged from 0.7 to 1.1 tons ha $^{-1}$ (Kementrian Pertanian, 2012).

The use of urea to produce maximum grain weight did not influence. The cause of the ineffectiveness 
Table 6. The interaction of SP-36 and $\mathrm{KCl}$ fertilizer on yield component

\begin{tabular}{|c|c|c|c|c|}
\hline \multirow{2}{*}{ SP-36 (kg. ha-1) } & \multicolumn{3}{|c|}{$\mathrm{KCl}\left(\mathrm{kg} \cdot \mathrm{ha}^{-1}\right)$} & \multirow{2}{*}{ Mean } \\
\hline & 0 & 75 & 150 & \\
\hline \multicolumn{5}{|l|}{ Number of seeds/plants } \\
\hline 0 & $33.40 \mathrm{~b}$ & $39.93 \mathrm{ab}$ & $32.96 \mathrm{~b}$ & 35.43 \\
\hline 150 & $37.33 \mathrm{ab}$ & $40.11 \mathrm{ab}$ & $46.69 \mathrm{a}$ & 41.38 \\
\hline 300 & $44.78 \mathrm{a}$ & $37.44 \mathrm{ab}$ & $45.44 \mathrm{a}$ & 42.56 \\
\hline Mean & 38.50 & 39.16 & 41.70 & $(+)$ \\
\hline Seed weight/plants & \multicolumn{4}{|c|}{ …................... g } \\
\hline 0 & $5.33 \mathrm{c}$ & $6.62 \mathrm{abc}$ & $5.18 \mathrm{c}$ & 5.71 \\
\hline 150 & $5.89 \mathrm{bc}$ & $6.83 \mathrm{abc}$ & $7.20 \mathrm{ab}$ & 6.64 \\
\hline 300 & $7.57 \mathrm{ab}$ & $6.34 \mathrm{abc}$ & $7.78 \mathrm{a}$ & 7.24 \\
\hline Mean & 6.26 & 6.61 & 6.72 & $(+)$ \\
\hline \multicolumn{5}{|l|}{ Seed weight/hectare } \\
\hline 0 & $1.31 \mathrm{c}$ & $1.77 \mathrm{ab}$ & $1.33 \mathrm{c}$ & 1.47 \\
\hline 150 & $1.54 \mathrm{bc}$ & $1.69 \mathrm{abc}$ & $1.98 \mathrm{ab}$ & 1.73 \\
\hline 300 & $1.88 \mathrm{ab}$ & $1.72 \mathrm{abc}$ & $2.02 \mathrm{a}$ & 1.88 \\
\hline Mean & 1.58 & 1.73 & 1.78 & $(+)$ \\
\hline
\end{tabular}

Remarks: Number followed by letter the same in the column indicated no significant difference according to DMRT at 5\% levels. Sign (+) indicated there was an interaction found between the factors tested.

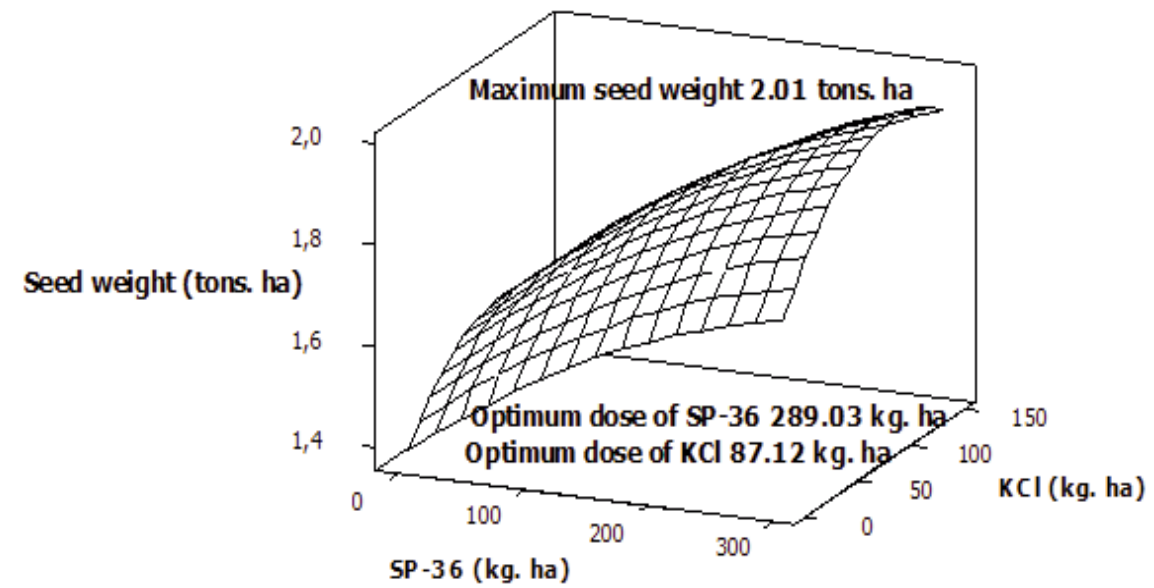

Figure 2. SP-36 and $\mathrm{KCl}$ treatment in the urea dose $0 \mathrm{~kg} \cdot \mathrm{ha}^{-1}$

of using urea fertiliser to seed yield might be related to the fulfillment of fertiliser given in the vegetative stage of plant growth and development. Plants which were treated without urea could still meet the needs of $\mathrm{N}$ through nitrogen fixation. Observations using isotope indicated that the content of $\mathrm{N}_{2}$ in the air was correlated with soybean root nodule formation (Schweiger et al., 2014). The dosage of fertiliser $\mathrm{N}$ required by soybean plants was lower compared with cereal crops, but soybean $\mathrm{N}$ uptake was greater than cereal crops. This could happen because soybean was capable of fixing $\mathrm{N}_{2}$ from air (Sisworo et al., 1985).

\section{CONCLUSION}

The optimum dosage was obtained, i.e. urea $0 \mathrm{~kg}$ ha $^{-1}$, SP-36 $289.03 \mathrm{~kg} \mathrm{ha}^{-1}$, and $\mathrm{KCl} 87.12 \mathrm{~kg} \mathrm{ha}^{-1}$ that was able to produce a maximum seed weight amounted to 2.01 tons ha $^{-1}$. Fertilisation using urea $50 \mathrm{~kg} \mathrm{ha}^{-1}, \mathrm{SP}-36300 \mathrm{~kg} \mathrm{ha}^{-1}, \mathrm{KCl} 150 \mathrm{~kg} \mathrm{ha}^{-1}$ was able to increase N, P, K uptake per hectare, amounted to $16.23 \mathrm{~kg} \mathrm{~N} \mathrm{ha}^{-1}, 86.27 \mathrm{~kg} \mathrm{P} \mathrm{ha}^{-1}$, and $0.02 \mathrm{~kg} \mathrm{~K}$ $\mathrm{ha}^{-1}$. The combination of urea with SP-36 and SP36 with $\mathrm{KCl}$ showed interactions in leaf area, photosynthetic rate, number of seeds per plant, seed weight per plants, and seed weight per hectare. 


\section{ACKNOWLEDGEMENT}

The author would like to thank profusely to LPPM (Agency for Research and Community Service) UGM which had funded this research through grants University (UGM LPPM / 371 / LIT / 2014).

\section{REFERENCES}

BPPN. 2013. Studi Pendahuluan Rencana Pembangunan Jangka Menengah Nasional (Rpjmn) Bidang Pangan dan Pertanian 2015-2019. [online] Badan Perencanaan Pembangunan Nasional, Direktorat Pangan dan Pertanian. Available at: http://www.bappenas.go.id/ [Accessed 10 January 2017].

BPS. 2015. Luas Lahan, Produksi dan Produktivitas Kedelai Menurut Provinsi 1993-2015. [online] Badan Pusat Statistik. Available at: http://www.BPS.go.id/ [Accessed 10 January 2017].

BPTP. 2008. Arahan Kesesuaian Lahan untuk Pengembangan Tanaman Kedelai Balai Pengkajian Teknologi Pertanian Yogyakarta. [online] Badan Penelitian dan Pengembangan Pertanian. Available at: http://www.yogya.litbang. pertanian.go.id/ [Accessed 10 January 2017].

Brant, A. N. and H. Y. Chen. 2015 . Patterns and Mechanisms of Nutrient Resorption in Plants. Critical Reviews in Plant Sciences, 34(5): 471-486.

Buckman, H. O. and N. C. Brady. 1969. The Nature and Properties of Soils. In: Soegiman, ed., Ilmu Tanah: Alih Bahasa. Jakarta: Bhratara Karya Aksara.

Chen, R., M. Senbayram, S. Blagodatsky, O. Myachina, K. Dittert, X. Lin and Y. Kuzyakov. 2014. Soil $\mathrm{C}$ and N Availability Determine The Priming Effect: Microbial N Mining and Stoichiometric Decomposition Theories. Global Change Biology, 20(7): 2356-2367.

Chiezey, U. F. and A. C. Odunze. 2009. Soybean Response to Application of Poultry Manure and Phosphorus Fertilizer in The Sub-Humid Savanna of Nigeria. J. Ecol. Nat. Environ, 1(2): 25-31.

Ceunfin, S., D. Prajitno dan P. Suryanto. 2015. Pengaruh Zonasi dan Jarak Tanam Jagung Pada Tumpangsari Jagung Kedelai di Bawah Tegakan Kayu Putih. Tesis. Universitas Gadjah Mada.

Daly, K., D. Styles, S. Lalor and D. P. Wall. 2015. Phosphorus Sorption, Supply Potential and Availability in Soils with Contrasting Parent Material and Soil Chemical Properties. European Journal of Soil Science, 66(4): 792-801.

Darmawijaya. 1992. Klasifikasi Tanah Dasar Teori
Bagi Peneliti Tanah dan Pelaksana Pertanian di Indonesia. Yogyakarta: Gadjah Mada University Press.

Fernández, V., P. Guzmán, C.A. Peirce, T.M. McBeath, M. Khayet and M. J. McLaughlin. 2014. Effect of Wheat Phosphorus Status on Leaf Surface Properties and Permeability to Foliar-Applied Phosphorus. Plant and Soil, 384 (1-2): 7-20.

Gardner, F. P., R.B. Pearce and R. L. Mitchell .1991. Fisiologi Tanaman Budidaya. In: Susilo, H., ed., Fisiologi Tanaman Budidaya Alih Bahasa. Jakarta: Universitas Indonesia (UI-Press).

Goldsworthy, P. R. and N. M. Fisher .1996. Fisiologi Tanaman Budidaya Tropik. In: Tohari, ed., Fisiologi Tanaman Budidaya Tropik Alih Bahasa. Yogyakarta: Gadjah Mada University Prees.

Kementrian Pertanian. 2012. Pengembangan Kedelai di Kawasan Lahan Hutan Jati Ngawi, 9 Januari 2012. [online] Available at: http://www.litbang. pertanian.go.id/berita/one/1070/ [Accessed 22 February 2017].

Prasetyo, B. H. 2007. Perbedaan Sifat-sifat Tanah Vertisol dari Berbagai Bahan Induk. J. IlmuIlmu Pertanian, 9: 20-31.

Purba, A. E., P. Yudono dan P. Suryanto. 2015. Produktivitas Jagung dan Kedelai Hitam Berdasarkan Jarak Tanam dan Zonasi Lahan Pada Tumpangsari Kayu Putih. Tesis. UGM.

Qiao, C., L. Liu, S. Hu, J. E. Compton, T. L. Greave and Q. Li. 2015 . How Inhibiting Nitrification Affects Nitrogen Cycle and Reduces Environmental Impacts of Anthropogenic Nitrogen Input. Global Change Biology, 21(3): 1249-1257.

Schweiger, P., M. Hofer, J. Vollmann and W. Wanek. 2014 . The Relationship Between N Isotopic Fractionation Within Soybean and $\mathrm{N}_{2}$ Fixation During Soybean Development. Physiologia Plantarum, 152(3): 546-557.

Sinaga, A., D. Indradewa dan P. Suryanto. 2016. Kajian Aplikasi Mikoriza dan Pemupukan N. P dan $K$ Terhadap Pertumbuhan dan Hasil Kedelai di Tegakan Kayu Putih. Tesis. Universitas Gadjah Mada.

Sisworo, W. H., H. Rasjid dan E. L. Sisworo .1985. Fiksasi Nitrogen Simbiotik Pada Kedelai Varietas Orba dan Lokon. BATAN: Pusat Aplikasi Isotop dan Radiasi.

Suryanto, P., B. Suwignyo, S. D. Prianto, E. T. S. Putra, and T. Alam. 2017. Morpho-physiological Characters and Soybean Productivity on Alfisol and Vertisol under Intercropping with Kayu Putih (Melaleuca cajuputi). Agrivita Journal of Agricultural Science, 39 (2): 153-159.

Tisdale, S. L., W. L. Nelson and J. D. Beaton. 1990. 
Soil Fertility and Fertilizer Elements Required in Plant Nutrition. 4th Edition. Singapore: Maxwell McMillan Publishing.

Xiang, D. B., T. W.Yong, W.Y. Yang, W. Z. Gong, L. Cui and T. Lei. 2012. Effect of Phosphorus and Potassium Nutrition on Growth and Yield of Soybean in Relay Strip Intercropping System.
Scientific Research and Essays, 7(3): 342351.

Zhu, X., W. Zhang, H. Chen and J. Mo. 2015 . Impacts of Nitrogen Deposition on Soil Nitrogen Cycle in Forest Ecosystems: A Review. Acta Ecologica Sinica, 35(3): 35-43. 